\title{
Research on Construction of Application-Oriented Undergraduate Key Course of Credit Management of Enterprises
}

Ming Zeng

School of Economy \& Management, Shanghai Second Polytechnic University, Pudong New District, Shanghai

Abstract-The guiding ideology of the key course Credit Management of Enterprises is for the purpose of credit management in corporate credit transactions, while the basic requirements of which is to promote the coordinated development of students' knowledge, ability and quality. As to the construction of teaching faculty, the establishing of "staff teachers and teaching staff" would be committed. As to lectures, the latest methods and cases from domestic and international corporate credit management should be closely connected, and students' professional interest and sensitivity should be developed. As to the construction of teaching conditions, the case that Shanghai Enterprise Credit Management Board Secretariat is in SSPU would be made the full use of, and the high quality of practical teaching environment would be established to realize the joint between industry and study.

Keywords - Application-oriented undergraduate, Credit management of enterprises, Course construction, Deep integration of industry and education

\section{应用型本科《企业信用管理》重点课程建设研究}

\author{
曾鸣 \\ 上海第二工业大学经济管理学院，上海，浦东新区
}

摘＼cjkstart要 《企业信用管理》重点课程建设的指导思想是以企业信用交易中的信用管理为目的，以促进学生知识、能力、素质协调 发展为基本要求。在师资队伍建设中, 致力于构建“员工型教师和教师型员工”的师资队伍。在课堂讲授中, 始终紧密联系国内外在企 业信用管理方面的最新方法和案例, 培养学生的专业兴趣和敏感度。在教学条件建设中, 将充分利用上海市企业信用管理专业委员会 秘书处设在二工大的有利条件，打造优质的实践性教学环境，实现产学无缝对接。

关键词＼cjkstart应用型本科，企业信用管理，课程建设，产教深度融合

1.引言

《企业信用管理》是应用型本科信用管理专业的核心 课程, 要求学生在扎实掌握知识的基础上, 使学生初步具 备企业信用管理的能力, 达到企业对信用管理人员上岗的 基本要求, 因而课程在教学中更要强调培养学生解决实际 问题的能力。虽然在以往的教学模式下, 学生能够熟练地 掌握企业信用管理的基本知识, 但对具体企业进行资信状 况分析, 有效开展企业信用管理却不知所措。基于此, 上 海第二工业大学将《企业信用管理》列入校级重点课程进 行建设, 希望该课程在培养应用技术型人才方面进行有益 的探索，笔者有幸担任了该项目的负责人。

\section{2.课程建设的指导思想与目标}

课程建设需要在党和国家教育方针政策的指导下，从 课程本身的特点出发, 综合考虑学校的实际情况和学生层 次的实际需要, 合理设定建设目标。大体上说, 《企业信 用管理》课程建设的指导思想和建设目标应达到以下要求。

\section{1 课程建设的指导思想}

认真贯彻党的十八届三中全会关于“深化教育领域综 合改革”的重要思想，贯彻落实《国务院关于加快发展现代 职业教育的决定》，遵循高等教育发展的基本规律，以企 
业信用交易中的信用管理为目的, 以网络技术、现代信息 技术为工具, 以信用经济、信用管理理论为基础, 系统地 构建企业信用管理基本方法。课程建设立足于以促进学生 知识、能力、素质协调发展为基本要求, 帮助学生掌握现 代信用管理理论与方法, 培养现代化高素质企业信用管理 人才, 促进教育教学质量不断提高。

\section{2 课程建设目标}

本课程是应用型本科信用管理专业的专业课。信用管 理专业的学生在毕业以后主要分布在企业、金融机构及资 信中介机构从事信用管理工作。因而工作的性质对本专业 的学生提出了更高的要求。

\subsection{1 凸显诚信的品质}

诚信是道德的范畴, 而信用则属于经济的范畴, 但诚 信是信用的基础和外在环境, 信用则是诚信的具体表现。 作为一名信用管理的工作者, 更应该具备诚信的品质。因 而《企业信用管理》课程在开发与建设过程中, 以诚信文 化为背景, 力图将诚信的理念贯穿于每一个知识点, 在教 学的每一个环节中不断融入诚信文化。

\subsection{2 扎实的专业知识}

对于优秀的信用管理人才, 应该以丰厚的专业知识储 备来胜任本职工作, 因而很难用“知识够用” 的原则来构建 教学内容体系。但是针对于应用型本科学生的特点, 以信 用管理部门各岗位的专业知识需求作为授课单元进行项目 化教学, 突破原有的《企业信用管理》的知识结构体系, 强调学科性的同时突出学以致用的特性。

\subsection{3 高人一筹的职业能力}

本课程是在充分调研及深入分析职业岗位能力的基础 上, 以建立客户信用档案、确定客户授信额度、应收账款 管理、初步的财务分析、客户失信预警、信用评价与报告 撰写等六大职业能力为核心, 以实践性教学为突破, 着重 强化学生根据实际情况解决问题的职业能力。

\section{3 课程定位}

《企业信用管理》课程将按照“知识+能力+素质”三位 一体的模式定位。知识是指学生通过课程学习应该掌握的 信用管理各个岗位必备的知识和技能, 如客户的信用信息 管理、客户的信用评价、客户的授信以及应收账款管理等。 能力则是在知识学习的基础上, 通过校内实训、校外工学 结合、顶岗实习的方式, 使学生具备将知识转化为实践操 作的职业能力。而素质则是在不断的知识学习和能力提升
过程中所积淀的一种品质。素质的养成不是一朝一夕的, 不能寄希望于通过一门课程的学习养成一种职业品质。所 以课程建设过程中, 在 “知识 + 能力+素质”三位一体的框架 下, 按照短期知识学习, 中期能力提升, 长期素质养成的 规划进行建设。

\section{3.师资队伍建设}

\section{1 原有师资队伍结构}

我们原来《企业信用管理》课程的师资队伍有 5 名, 全 部具有高级职称, 其中 1 名拥有博士学位。年龄结构为: 40 岁以下 1 名, 40岁至 45 岁 2 名, 45岁以上 2 名, 知识结构包含 了经济学类的不同专业背景。但这样的师资队伍结构明显 不适合应用型本科专业《企业信用管理》重点课程建设的 要求。

\section{2 构建“员工型教师和教师型员工”的师资队伍}

李克强总理在2014年2月26日主持召开的国务院常务 会议上指出, 要“充分调动社会力量, 吸引更多资源向职业 教育汇聚, 加快发展与技术进步和生产方式变革以及社会 公共服务相适应、产教深度融合的现代职业教育。”我们 认为: 产教深度融合是培养应用技术型人才的需要。为此, 我们致力于构建“员工型教师和教师型员工”的师资队伍。 所谓构建员工型教师的师资队伍, 就是把主讲企业信用管 理的教师安排到信用管理行业的单位兼职, 按照企业员工 的要求完成一定数量的业务活动。目前, 已有一名教师在 上海地区的某信用服务公司兼职了一年, 承担公司的具体 业务。所谓构建教师型员工的师资队伍, 就是聘请企业信 用管理行业的优秀骨干员工担任企业信用管理课程的兼职 教师, 按照上海第二工业大学的教师要求完成一定数量的 授课任务。目前, 我们已聘请了上海市企业信用互助协会 的秘书长担任企业信用管理课程的兼职主讲教师。

\section{4.教学条件建设}

\section{1 大纲、试卷库、教材建设方案}

由于我校注重培养应用型人才, 因而信用管理专业的 学生与中国人民大学、上海财经大学等同专业学生有着不 同的培养目标。为此, 我们采取的一些措施: (1) 不断更 新和完善本课程的教学大纲; (2) 不断补充和更新试卷, 完成试卷库建设; (3) 编写适合我校学生特点和培养目标 的企业信用管理教材。 


\section{2 利用扩充性资料促进学生主动学习}

扩充性资料分为纸张型和非纸张性两类。前者主要包 括教师指定阅读的国内外参考文献, 包括部分相关的原著 和经济学方面的杂志, 开阔学生的知识面; 后者主要是指 课件和网上阅读材料。从原先使用情况看, 课件资料的使 用情况较好, 其次是相关的教材和文献。我们将在此基础 上, 结合建设上海自贸试验区的新形势, 进一步收集并利 用好扩充性资料, 从而提高学生的学习兴趣和学习效率。

\section{3 实践性教学环境建设}

目前我们已经拥有能容纳 80 人同时上机的学校重点 实验室, 配置了一批教学实验所需经济分析的软件, 供学 生进行数据分析与处理。并通过举办经济小论文竞赛和聘 请校外专家进行专题讲座, 锻炼学生的动手能力和逻辑思 维的能力以及培养学生的团队合作精神。今后我们将充分 利用上海市企业信用管理专业委员会秘书处设在我校的有 利条件, 打造优质的实践性教学环境, 实现产学无缝对接。

\section{4 网络教学环境建设}

我们将建立和完善网络教学环境。我们已经初步基本 完成了《企业信用管理》课件的建设, 形成了课程内容讲 解、重点难点分析、案例分析、作业点评、课程论文、教 学讨论、网上课程答疑等栏目, 并根据情况变化及时进行 充实、调整, 等内容完成后择机上网, 建成《企业信用管 理》课程网站。同时, 任课教师向学生公布电子信箱, 经 常通过电子邮件进行师生教学交流, 以取得良好的教学效 果。

\section{5.教学方法与教学手段建设}

我们采取多种教学方法, 培养学生对《企业信用管理》 的学习兴趣:

\section{1 完善课堂讲授}

在课堂讲授中, 首先是始终紧密联系国内外在企业信 用管理方面的最新方法和案例, 以提高学生的理论修养, 培养学生的专业兴趣和敏感度; 其次是及时将企业信用管 理的基本原理同国家信用管理方面的最新法律法规和最新 举措结合起来进行探讨。

\section{2 召开座谈会}

每学期组织一次由任课教师和各班学生代表参加的座 谈会, 就学习中存在的疑难问题、热点问题进行交流, 加
强教与学的沟通。

\subsection{PPT课件优化}

目前已经制作了课程的课件和相应的幻灯片, 课件突 出了学习中的重点和难点问题。今后将在此基础上进一步 优化, 并增加一些图片和图表, 有利于学生全面把握课程 的精髓, 从而增进课堂教学的效果。

\section{4 在线辅导}

在线辅导分为定期和不定期两种方式。定期辅导是教 师和学生在约定的时间和约定的聊天室, 进行集中的答疑 辅导。不定期辅导分为两类, 一类是学生将问题以电子邮 件的方式发给教师, 教师及时通过电子邮件答复; 另一类 是教师和学生通过网络直接交流。

\section{6.《企业信用管理》重点课程建设的努力方向}

\section{1 进一步加强教学方法的改革}

《企业信用管理》重点课程的教学方法改革, 要根据 课程的性质和任务, 以工作流程为主线, 积极推行案例分 析法、情景模拟法、小组研讨法、实践教学法、项目教学 法等多种教学方式。而且在改革中, 要认真研究与思考根 据不同的学生、不同的教学项目, 采用不同的教学方法, 努力做到因材施教。

\section{2 进一步扩展紧密型实践教学基地的建设}

培养学生动手操作能力是应用型本科院校一个鲜明的 特色, 必须加强实践性的教学。而实践性教学基地是实践 教学的重要保障, 也是培养学生素质与能力的手段之一。 目前, 影响实践性教学基地在教学中发挥应有作用的原因 主要在于校企合作并非双赢模式, 企业在合作中处于被动 态势, 合作没有使企业受益。这种紧密型的实践教学基地 不仅有信用服务中介机构, 还应该有政府信用监管部门、 企事业单位以及金融机构，使信用管理实践教学基地多样 性。希望通过《企业信用管理》重点课程的建设, 在企业、 金融机构以及政府信用监管等部门开拓深度合作的实践教 学基地。

\section{7.结束语}

应用型本科重在“应用”二字，《企业信用管理》重点 课程建设是一项较复杂的系统工程, 应以职业能力为本位 进行课程目标建设, 基于工作过程系统化设计教学内容, 采用新的教学方法和手段, 不断提高教学水平, 培养具有 
较强社会适应能力和竞争能力的高素质应用型人才。同时, 重点课程建设本身也是一个教学实践和教学研究的过程, 需要不断地完善和充实, 因此, 应用型本科的《企业信用 管理》重点课程建设还需要在教学实践中深入探索。

\section{致谢}

本文获上海第二工业大学金融学培育学科专项资助 (编号：XXKPY1306), 在此谨致谢意。

\section{参考文献（References）}

[1] JingMei Wu, Reflections on Professional Construction of Credit Management, China Higher

Education Research,
[2] Fan Teng, QingWei Zhang, Discussion on Course Construction of "Financial Derivatives" in Applied Undergraduate Colleges, China Electric Power Education, 2011(8): 122-123

[3] Ping Wang, Discussion on the Significance and Ways in Construction of the Course Network Credit Management, Education Online, 2011(5):145-146

[4] FeiFei Yu, Zhongming Zuo, Study on Course Construction of Food Service and Management in Application-oriented Universities, Journal of Chizhou College, 2011(6): 134-136

[5] YuSheng Lou, Analysis of the Development and Construction of Quality Courses, Heilongjiang Researches on Higher Education, 2012(4):150-153. 